\section{PARTICIPATION IN BRAZILIAN FEMINIST MOVEMENTS ON SOCIAL NETWORKS: a study on the campaign Meu Amigo Secreto (My Secret Santa)}

\author{
Gustavo Hermínio Salati Marcondes de Moraes * \\ Juliana Boldrin** \\ Danilo Soares Silva
}

Keywords: Internet. Social networks. Feminism. Online social movements.

\footnotetext{
* Doutor em Administração pela Fundação Getúlio Vargas, Brasil. Professor da Faculdade de Ciências Aplicadas da Universidade Estadual de Campinas, Brasil. E-mail: gustavo.salati@fca.unicamp.br.

** Mestranda do Programa de Mestrado em Desenvolvimento, Tecnologias e Sociedade da Universidade Federal de Itajubá, Brasil. Graduada em Administração pela Universidade Estadual de Campinas, Brasil.

E-mail: jujuboldrin@gmail.com.

*** Graduado em Engenharia de Produção pela Universidade Anhembi Morumbi, Brasil. Mestrando do Programa de Engenharia de Produção e Manufatura da Faculdade de Ciências Aplicadas da Universidade Estadual de Campinas, Brasil.

E-mail: daniloss23@hotmail.com.
}

\section{INTRODUCTION}

$\mathrm{n}$ the 19th century, many women have
organized themselves to question how they
were inserted in society. In principle, the
claim was to voting power, and women who protested were known as suffragettes, and this period was known as the first wave of feminism.

Feminism claimed a transformation of gender relations in public and private domains of social life. The emergence of modern urban industrial society, marked by the entry of women in the labor market, which expanded over the 
course of the 20th century, was what propitiated the feminism, thus forming its second wave. With a double working day, women began to occupy public space with the insertion in paid employment and in formal education, and the contradictions of the private space intensified (SCAVONE, 2008).

Currently, one of the strains of existing feminisms is the intersectionality, which proposes to understand how relations between various sets of dependency are composed. How racism, patriarchalism and class oppression form the inequalities that build relationships of gender, race and class, and how actions originate oppressions over time through the constructed dynamism (CRENSHAW, 2002).

Recently, women have been using social networks as a way to help denounce cases of harassment and organize activities and protests, thus enabling a greater and faster formation of feminist groups in the virtual media and also in spaces such as universities, businesses and streets. In Brazil, feminist movement and women's movements mobilized the groups through campaigns (online) to denounce the various expressions of violence directed at women (CÔRTES; ARAUJO; SILVA, 2014).

According to Tomaél, Alcará and Di Chiará (2005), the inclusion in network is decisive for disseminating information and knowledge, because the networks form suitable environments for appreciation of information sharing and for building knowledge.

Social networks are an important means of action to support movements or actions against social and political injustices (BENNETT; SEGERBERG, 2011; GIL DE ZÚÑIGA; JUNG; VALENZUELA, 2012; TUFEKCI; WILSON, 2012; OH; AGRAWAL; RAO, 2013).

In this context, this study aims to identify which are the elements that influence the Intention of Participation of women in feminist movements online, through a study on the campaign \#meuamigosecreto (\#mysecretsanta) in Brazil.

According to França, Neto and Dias (2015), the information enables to better understand the social environment. For Côrtes, Araújo and Silva (2014, p. 91), information is essential "to change the perverse situation of inequality that affects the lives of thousands of women every day". This way, results of this study can provide relevant information to a greater understanding of the feminist movements online, demonstrating the beliefs and differences between the motivations of participants in movements on the internet.

The survey fills an important gap in researches on digital activism (AGARWAL et al., 2014; GHOBADI; CLEGG, 2015; LEONG et al., 2015; OH; AGRAWAL; RAO, 2013; WATTAL et al., 2010). Researches on the theme have achieved important progress in the understanding of short-term critical events and actions, but many contexts have not been exploited yet. The study also contributes to a greater understanding of the influence of social media on the political activism and collective action (BENNETT; SEGERBERG, 2011; GIL DE ZÚÑIGA; JUNG; VALENZUELA, 2012; TUFEKCI; WILSON, 2012).

\section{INFORMATION SCIENCE AND SOCIAL MOVEMENTS}

According to Nhacuongue and Ferneda (2015), Information Science is a scientific field under construction, because for Capurro and Hjorland (2007), Information Science was born in the 1950s, combined with the development and dissemination of computer use, at the end of World War II, however there are researchers who suggest traces of this area before the post-World War II period.

For Nhacuongue and Ferneda (2015, p.10), the Information Science was developed as a science of an essentially technical nature to solve the informational problems of society. It is an area that plays an important social role, "not only by focusing on the human dimension in relation to technology, but also in the process of transformation by information" (NHACUONGUE; FERNEDA, 2015, p. 10).

Saracevic (1996) defined three characteristics for Information Science: interdisciplinarity in its nature, its connection with technology and its active role in the evolution of the information society. He suggests that Information Science plays a significant role because of her social and human dimension that surpasses the technology. This means Information Science can contribute to mitigate social issues.

Social movements have become the crucial point of participatory democracy, due to constant 
struggles for social participation throughout the world's history. Popular mobilizations that have taken place in June 2013 in Brazil demonstrate how social movements are in a rearticulation process and how they are strengthening (ARAÚJO; FARONE, 2015).

Even being collectively formed, social movements are heterogeneous, because inside them there are different modes of strategies and actions developed by the social actors that compose them, therefore social movements are merely characters in a previously fixed structure (MELUCCI, 2001). This heterogeneity can be seen as the popular access to claim their rights or participation in the democratic process of public policies according to a specific context (ARAÚJO; FARONE, 2015).

Social movements create new forms of action, at their ends and means, with strong symbolic content, being oriented towards precise objectives, concrete and important for the social life (BORDIEU, 2001). The links and associations among the actors of social movements are formed by channels of information and flow of resources (OBACH, 2004; VAN DYKE; MCCAMMON, 2010).

Organizers of social movements frequently share information on the strategies to be used, events relevant to the movement and ideas for new performances (WANG; SOULE, 2012).

The more coordinated are individuals within interdependent networks, the greater the chance of success of a social movement. Some studies have shown that the understanding of the structure of these associations help in understanding a variety of results of movements (BEARMAN; EVERETT, 1993; GOULD, 1993; PUTNAM, 1993; BALDASSARI; DIANI, 2007).

In this way, social networks play a crucial role for propagation of information pertaining to the movement because it connects people instantly (MORAES; CAPPELLOZZA; MEIRELLES, 2014). For Boyd and Ellison (2007), social networks increasingly draw the attention of users and researchers due to its characteristics and range.

However, the use of social networks is not a guarantee of success of the movements. Results of the study conducted by Moraes, Cappellozza and Meirelles (2014) to identify the factors that led people to use social networks for participation in protests that occurred in
Brazil in 2013, demonstrate disbelief about some positive effect to the solution of problems. Even so, people were protesting and had intended to continue protesting in virtual form.

\section{I "My secret santa" and "my first harassment" campaigns}

According to Warren (2006), social movements networks allow the transposition of territorial borders through interactions of local actions with regional, national and transnational ones; the transposition of time through the combat against the non representation of human rights historically; as for the social transposition in a broader sense, it means understanding the pluralism of various conceptions of world within ethical boundaries, respecting differences and radicalization of democracy by strengthening the autonomy concerning the formed civil society.

Before a backdrop of mobilization for the questioning of women in Brazilian society, in November 2015, women organized and created a new campaign through social networks such as Facebook and Twitter, the campaign began on November 23 $3^{\text {rd }} 2015$, with the hashtag \#meuamigosecreto (\#mysecretsanta), beginning with a tweet from the feminist community profile "Não me Kahlo", which read: "My secret Santa says that abortion is murder, but asked his girlfriend to abort when she became pregnant.", this same tweet was posted on the Facebook community "Não me Kahlo" reaching 7,000 likes in this publication.

Warren (2006) introduces the concept of social movement network, which we can apply to the previously described movement.

\begin{abstract}
The idea of social movement network is, therefore, a concept that seeks to understand the future or direction of the movement actions, transcending the empirical, concrete, dated, located experiences of the collective subject/ actors. (WARREN, 2006, p. II3).
\end{abstract}

The campaign Meu Amigo Secreto (My Secret Santa) was created to denounce cases of machismo that women had experienced, whether by close people, or even by acquaintances and unknown people, i.e., contacts in schools, streets, or work through a tradition adopted in end-of- 
year parties, the secret Santa, or how it is called in Brazilian Portuguese, amigo secreto (secret friend). The height of the campaign was on November $25^{\text {th }} 2015$, on International Day for the Elimination of Violence Against Women. According to the World March of Women, it was not necessary to use the names of secret friends for other women to identify them, since many reports are fruit of the society's macho culture.

Another virtual campaign carried out by women was Meu primeiro assédio (My first harassment); this campaign was created by @ ThinkOlga, a think thank (knowledge producers) that discusses feminist issues via internet. According to Faria (2015), one of the campaign creators, the idea came about after the premiere of a children's cooking show on an open television channel in October 2015, in which after the premiere there were several pedophile comments on Twitter about one of the 12-yearold participants.

The comments brought outrage in social networks; given this, Faria (2015) decided to encourage women to start a campaign via social networks, in which they could tell how was the first harassment they suffered, according to the creator of the campaign, the hashtag MeuPrimeiroAssedio (MyFirstHarassment) was the hashtag of transformation.

\begin{abstract}
We invite our readers to do the same. It is not a simple, painless and easy mission. But to seize your own history is important, so that the victim is recognized as a victim. It is not victimhood. It is empowering to see that oppression is, indeed, an oppression and not "part of life". This is the first and most important step for change. (FARIA, 20I5).
\end{abstract}

With the use of the hashtag, the creator claims that until October $26^{\text {th }} 2015$, it had reached 82,000 tweets that helped in the empowerment of women, also having international repercussion. The hashtag was used by women in Britain, United States, Chile, Portugal and the Netherlands, where women reported the first moments in which they felt embarrassed or threatened by comments or sexual advances.

According to Timoteo (2013), despite being considered a new social movement, the Brazilian feminist movement has exceeded the limits of its status and of the very concept, going beyond demand and political influence on the grounds of the specific interests of the movement, that is, it entered in the State, interacted with it and still remains as an independent movement.

\subsection{Theory of planned BEhavior}

According to Buscht (1998), the relations between attitudes and behavior have been intensely discussed in the social and behavioral sciences in recent years.

The theory of reasoned action (TRA), Fishbein and Ajzen (1975), suggests that individual behavior is determined by the person's intention to perform a behavior, and that such intention is determined by the attitude towards the behavior and subjective norms (FISHBEIN; AJZEN, 1975). For the authors, to understand the factors that affect the behavior it is necessary to understand the determinants of normative components and attitude, which are individual beliefs that people have of themselves and of the context in which they are inserted.

Developed as an extension of the theory of reasoned action, the theory of Planned Behavior (TPB) considers in addition to the variables of TRA, the perceived behavioral control variable. Such variable influences both intention and consumer's behavior. According to Ajzen and Fishbein (1980), authors of the TPB, the relative importance of Attitude, Subjective norm, and Perceived Behavioral control on prediction of Intention should vary according to the different behaviors and situations to which the theory is applied.

The TPB authors suggest that human behavior is based on behavioral beliefs, normative beliefs and beliefs about control.

Behavioral beliefs address possible consequences of human behavior and lead to a favorable or not favorable behavioral attitude. In relation to normative beliefs, they refer to perceived behavior expectations regarding other people, such as family and friends, which would be the social pressure in behavior. On the other hand, beliefs about control refer to factors that may facilitate or impede the performance of behavior of the individual.

Taking these three aspects into account, the theory proposes that the power exercised by Attitude, Subjective Norm and Perceived 
Control determines the Behavioral Intention (AJZEN, 2008). The higher the Perceived Control and when the Attitudes and Subjective Norms are favorable, the behavioral intention will be stronger.

As the study focus on predicting the Behavioral Intention related to the women's participation in feminist movements, the TPB has proved itself adequate for the research purposes, and the study hypotheses are based on theory.

\section{CONCEPTUAL MODEL OF RESEARCH AND STUDY HYPOTHESES}

From the literature review and formulation of hypotheses, a model was elaborated to meet the survey purpose (Figure 1), which aims to identify what are the elements that influence the women's intention of participation in feminist movements online. The visual representation facilitates the understanding of the theoretical model proposed (WHETTEN, 1989).

Figure 1. Conceptual model of research

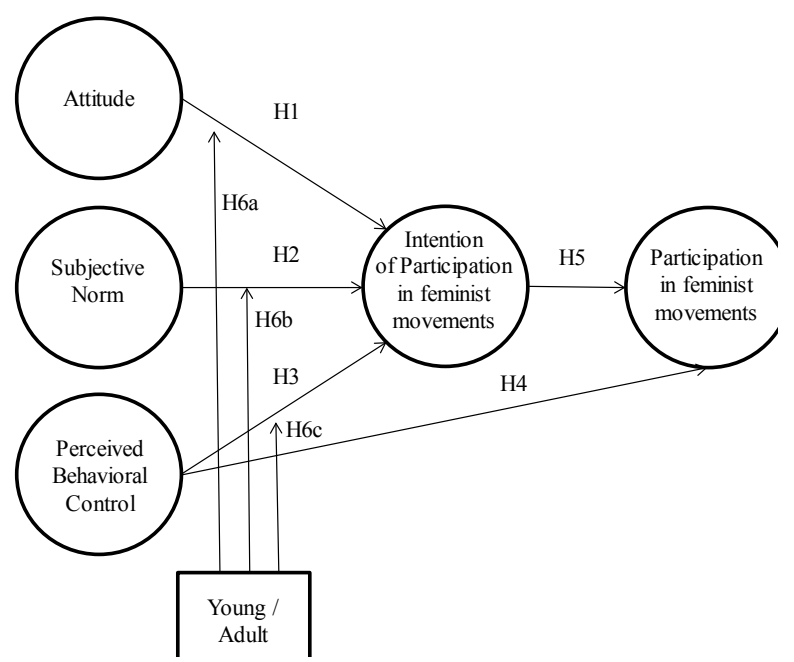

Source: own

Table 1 presents the description of study hypotheses. Hypotheses 1, 2, 3, 4 and 5 were based on TPB. The hypothesis 6 was based on studies related to the adoption of information technologies (VENKATESH; MORRIS; DAVIS;
DAVIS, 2003; VENKATESH; THONG; XU, 2012) that consider the possibility of certain individual characteristics of influencing the relationship of background factors to the use of technologies, such as age, gender and other variables. In the case of participation in feminist movements, it is understood that the perception of young women may be different from the perception of adult women.

Table 1. Hypotheses of the study

\begin{tabular}{|l|l|}
\hline Hypotheses & \multicolumn{1}{|c|}{ Description } \\
\hline H1 & $\begin{array}{l}\text { The Attitude towards participation in } \\
\text { feminist movements positively influences } \\
\text { the Intention of Participation in the feminist } \\
\text { movements online. }\end{array}$ \\
\hline H2 & $\begin{array}{l}\text { The Subjective Norm influences positively } \\
\text { the Intention of Participation in feminist } \\
\text { movements online. }\end{array}$ \\
\hline H3 & $\begin{array}{l}\text { The Perceived Behavioral Control positively } \\
\text { influences the Intention of Participation in } \\
\text { feminist movements online. }\end{array}$ \\
\hline H4 & $\begin{array}{l}\text { The Perceived Behavioral Control positively } \\
\text { influences the Intention of Participation in } \\
\text { feminist movements online. }\end{array}$ \\
\hline H5 & $\begin{array}{l}\text { The Intention of Participation in feminist } \\
\text { movements online positively influences the } \\
\text { Participation in movements. }\end{array}$ \\
\hline H6a & $\begin{array}{l}\text { The woman's age moderates the relationship } \\
\text { between Subjective Norm and Intention of } \\
\text { Participation in feminist movements. } \\
\text { Intention of Participation in feminist } \\
\text { movements. }\end{array}$ \\
\hline \multirow{2}{*}{ H6c } & $\begin{array}{l}\text { The woman's age moderates the relationship } \\
\text { between perceived Behavioral control and } \\
\text { Intention of Participation in feminist } \\
\text { movements. }\end{array}$ \\
\hline
\end{tabular}

Source: own

\section{METHODOLOGICAL ASPECTS}

The survey was developed through a quantitative methodology, with the use of multivariate data analysis. According to the suggestions of Hair, Hult, Ringle and Sarstedt 
(2013), where the theories about feminist movements online are poorly developed and the goals are prediction and explanation of the constructs presented, we opted for the use of Partial Least Squares Path Modeling (PLSSEM). The model developed for survey presents reflective and formative indicators, which is another reason to use the PLS-SEM (CHIN; NEWSTED, 1999; HAIR; HULT; RINGLE; SARSTEDT, 2013).

To assess the face validity of the questionnaire, a pre-test was conducted with collaboration of five potential respondents (Brazilian women active in feminist movements). In a supplementary form, the questionnaire was submitted to the scrutiny of specialists in research of technological adoption and structural equation models for assessing the validity of the assertions content (NETEMEYER; BEARDEN; SHARMA, 2003). The scales were adapted from previous studies.

The link with the survey questionnaire was posted on social networks, in national groups of feminist movements online, with a presentation of the research. In addition, the questionnaire was sent directly to Brazilian women who have posted and shared messages with the hashtag meu amigo secreto. Some questionnaires had to be discarded, in such a way that the studied sample contains 185 Brazilian women participants of the movement. Data collection lasted 30 days and was held in December 2015.

The survey questionnaire was developed and applied in Brazilian Portuguese, but Table 2 presents the measuring instrument indicators translated into English.

Table 2. Measuring instrument scale indicators

\begin{tabular}{|c|c|c|}
\hline Construct & Indicator & Question \\
\hline \multirow{4}{*}{ ATTITUDE } & AT1 & $\begin{array}{l}\text { I believe that participating in \#meuamigosecreto through social networks strengthens } \\
\text { the feminist movement. }\end{array}$ \\
\hline & AT2 & $\begin{array}{l}\text { I believe that denunciation through social networks makes men become aware of their } \\
\text { macho attitudes. }\end{array}$ \\
\hline & AT3 & $\begin{array}{l}\text { I think that reporting cases of machismo with \#meuamigosecreto can result in a } \\
\text { decrease in cases of violence against women. }\end{array}$ \\
\hline & AT4 & $\begin{array}{l}\text { I think the campaign \#meuamigosecreto can contribute to the debate on violence } \\
\text { against women. }\end{array}$ \\
\hline PERCEIVED & BC1 & I find easy to share reports with \#meuamigosecreto posted on social networks. \\
\hline BEHAVIORAL & $\mathrm{BC} 2$ & I find easy to like and comment on reports on social networks. \\
\hline CONTROL & $\mathrm{BC} 3$ & I find easy to find texts containing the hashtag meuamigosecreto on social networks. \\
\hline \multirow{4}{*}{ SUBJECTIVE NORM } & SN1 & $\begin{array}{l}\text { People who influence my behavior support my participation in actions of support to } \\
\text { the women's struggle in social networks. }\end{array}$ \\
\hline & SN2 & $\begin{array}{l}\text { People from my personal circle think I should participate in online actions to combat } \\
\text { machismo. }\end{array}$ \\
\hline & SN3 & $\begin{array}{l}\text { My friends support and advise me to participate in feminist movements in social } \\
\text { networks. }\end{array}$ \\
\hline & SN4 & $\begin{array}{l}\text { Many people who influence my behavior took part in the \#meuamigosecreto campaign, } \\
\text { influencing my participation. }\end{array}$ \\
\hline \multirow{4}{*}{$\begin{array}{l}\text { INTENTION OF } \\
\text { PARTICIPATION }\end{array}$} & IU1 & I intend to participate in feminist actions through the internet in the future. \\
\hline & IU2 & $\begin{array}{l}\text { In the next } 12 \text { months, I intend to adhere to new actions of the women's movement } \\
\text { through the internet. }\end{array}$ \\
\hline & IU3 & I intend to combat violence against women through social networks in the future. \\
\hline & IU4 & I intend to use social networks to participate in new actions against machismo. \\
\hline \multirow{4}{*}{ PARTICIPATION } & USE1 & I participated in the campaign \#meuamigosecreto through social networks. \\
\hline & USE2 & $\begin{array}{l}\text { I liked publications on social networks that denounced macho attitudes with the } \\
\text { hashtag meumigosecreto. }\end{array}$ \\
\hline & USE3 & I shared publications containing the hashtag meumigosecreto. \\
\hline & USE4 & $\begin{array}{l}\text { I posted messages on social networks denouncing attitudes of people I knew with the } \\
\text { hashtag meuamigosecreto. }\end{array}$ \\
\hline
\end{tabular}

Source: own 
To evaluate the sample size and statistical power of the analyses, it was conducted an analysis with the software G*Power 3 (FAUL; ERDFELDER; LANG; BUCHNER, 2007) and for recommendations of Chin and Newsted (1999), Cohen (1988) and Hair, Hult, Ringle and Sarstedt (2013). The largest amount of arrows that come to a latent variable is 3 (higher quantity of predictors). Considering 3 predictors, a significance level of $5 \%$, statistical power of 0.8 and average effect size ( $\mathrm{f}^{2}=0.15$, which is equivalent to $\mathrm{r}^{2}=$ $13 \%)$, the minimum size of the sample is 77 . As the sample used was 185 people, it is suitable for estimation by Partial Least Squares for Path Modeling (PLS-PM). The analyses a posteriori (post hoc) for the sample obtained indicate that: (a) any $\mathrm{r}^{2}$ higher than $5.6 \%$ would be detected as significant, keeping the power of 0.8 and the $5 \%$ significance level; and (b) to the average effect size the power is of 0.996, which is well above the value 0.8 , recommended by Chin and Newsted (1999) and Hair, Hult, Ringle e Sarstedt (2013).

The questions were measured using a seven-point Likert scale, as well as it occurred in surveys that used similar models. The respondent answered with variations between the extremes Strongly Disagree to Strongly Agree. The questions were in random order in the questionnaire.

SmartPLS software 3.0. M3 (RINGLE; WENDE; BECKER, 2015) and IBM SPSS Statistics 21 were used for calculations and validations of statistical tests, developed by means of multivariate analysis technique of structural equation modeling.

\section{DESCRIPTION AND RESULTS ANALYSIS}

The model features reflective indicators (Attitude, Subjective Norm, Perceived Behavioral Control and Intention of Participation) and an indicator of formation (Participation in movements), thus each indicator will be evaluated in accordance with the appropriate criteria.

\section{I Evaluation of formative measurement models}

The criteria for evaluation of formative measurement models are: convergent validity, multicollinearity analysis and significance and relevance (HAIR; HULT; RINGLE; SARSTEDT, 2013).

Convergent validity was accomplished through the redundancy analysis. This analysis was done through the correlation of variables of the formative construct with a global measure of the indicator. The construct was modeled as the independent variable and the global measure as dependent variable. According to Hair, Hult, Ringle e Sarstedt (2013), a path coefficient above the threshold of 0.80 provides support for convergent validity of the formative construct. In the case of the construct Participation in feminist movements online, the value was 0.905 , providing support for convergent validity.

The software IBM SPSS Statistics 21 was used to test collinearity of indicators. It was held a multiple regression of the formative construct indicators with any other indicator, and all values are within the established; tolerance values are above 0.20 and VIF values are below 5 .

The bootstrapping technique in SmartPLS was used to analyze the significance and relevance. According to the t-statistics of outer weights, the indicators PART3 and PART4 are significant, but the variables PART1 and PART2 are not. However, Hair, Hult, Ringle e Sarstedt (2013) recommend analyzing the outer loadings too. In the analysis of the T-statistics of outer loadings, all variables are significant $(p<0.01)$. In this case, recommendation is to keep the variables in the model.

\subsection{Evaluation of reflective measurement models}

The criteria for evaluating reflective measurement models, according to Hair, Hult, Ringle e Sarstedt (2013) are: internal consistency (composite reliability); reliability of the indicator; convergent validity (average variance extracted); discriminant validity.

The convergent and discriminant validities were assessed at the level of indicators and of the latent variables. Almost all indicators presented high factorial loadings in their latent variables (Table 3), greater than 0.70 (convergent validity), and low factorial loadings in the other latent variables (discriminant validity), indicating reasonable convergent and discriminant validity 
(CHIN, 1998). The exceptions were the variables AT2, which presented the value of $0.403, \mathrm{SN} 4$, which presented the value of 0.631 , and SN2, with the value of 0.691 . Composite reliability and Cronbach's Alpha indicators of the constructs of these variables were analyzed and we chose to eliminate the variables AT2 and SN4 not to undermine further analyses, according to the suggestions of Hair, Hult, Ringle e Sarstedt (2013).

Table 3. Crossed factorial loadings

\begin{tabular}{clcccc}
\hline Construct & Variable & Attitude & $\begin{array}{c}\text { Subjective } \\
\text { norm }\end{array}$ & $\begin{array}{c}\text { Behavioral } \\
\text { control }\end{array}$ & $\begin{array}{c}\text { Intention o } \\
\text { participatio }\end{array}$ \\
\hline \multirow{2}{*}{ Attitude } & AT1 & $\mathbf{0 . 7 9 2}$ & 0.248 & 0.231 & 0.447 \\
& AT2 & $\mathbf{0 . 4 0 3}$ & 0.09 & 0.154 & 0.22 \\
& AT3 & $\mathbf{0 . 7 5 6}$ & 0.206 & 0.203 & 0.433 \\
& AT4 & $\mathbf{0 . 7 3 9}$ & 0.131 & 0.128 & 0.393 \\
Subjective norm & NS2 & 0.137 & $\mathbf{0 . 7 1 8}$ & 0.056 & 0.263 \\
& NS3 & 0.175 & $\mathbf{0 . 6 9 1}$ & 0.145 & 0.278 \\
Behavioral & NS4 & 0.18 & $\mathbf{0 . 7 4 7}$ & 0.117 & 0.272 \\
control & CC1 & 0.211 & 0.113 & 0.246 & 0.324 \\
& CC3 & 0.237 & 0.226 & $\mathbf{0 . 7 3 1}$ & 0.276 \\
& IP1 & 0.167 & 0.152 & $\mathbf{0 . 8 1 9}$ & 0.35 \\
Intention of & IP2 & 0.486 & 0.402 & 0.258 & 0.282 \\
participation & IP3 & 0.399 & 0.286 & 0.371 & $\mathbf{0 . 8 3 4}$ \\
& IP4 & 0.44 & 0.3 & 0.297 & $\mathbf{0 . 8 3}$ \\
\hline
\end{tabular}

Source: own

Another indicator used for the convergent validation of the model is the value of the average extracted variance (AVE) which must present a value greater than 0.5 as a validation criterion (HAIR; RINGLE; SARSTEDT, 2011).

To evaluate the measurement model, besides examination of the loading for each indicator, a main measure used is composite reliability of each construct (HAIR; ANDERSON; TATHAM; BLACK, 2005; HAIR; HULT; RINGLE; SARSTEDT, 2013). Composite reliability describes the degree to which the indicators represent the latent construct in common. An acceptable and commonly used reference value for reliability is 0.70 .

To analyze the convergent validity, internal consistency was verified. A high value of internal consistency in the construct indicates that all the variables represent the same latent construct. Internal consistency is evaluated through the Cronbach's Alpha, which varies from 0 to 1 , with high values indicating a higher level of consistency. For exploratory studies, values between 0.60 and 0.70 are considered acceptable; but for studies at more advanced stages, values between $0.70 \quad 0.90$ are considered satisfactory (NUNALLY; BERSTEIN, 1994; HAIR; HULT; RINGLE; SARSTEDT, 2013).

Another indicator of discriminant validity between the constructs is to calculate the square root of the average variance extracted from constructs, this value must be greater than the correlation between latent variables (FORNELL; LARCKER, 1981). 
All mentioned indicators are presented in Table 4 and are within the established by the authors, except for the value of Cronbach's Alpha for Attitude and Subjective Norm, which presents values just below the adequate. However, according to Hair, Hult, Ringle e Sarstedt (2013) the Cronbach's Alpha is sensitive to the number of scale items and usually tends to underestimate the internal consistency, being more appropriate to carry out the evaluation through composite reliability, in which the indicators presented adequate values.

The value presented diagonally, in bold, is the square root of the average variance extracted.

Table 4. Summary of the evaluation of measurement models

\begin{tabular}{|c|c|c|c|c}
\cline { 2 - 5 } \multicolumn{1}{c|}{} & Attitude & $\begin{array}{c}\text { Subjective } \\
\text { norm }\end{array}$ & Behavioral control & $\begin{array}{c}\text { Intention of } \\
\text { participation }\end{array}$ \\
\hline Attitude & $\mathbf{0 . 7 7 9}$ & & & \\
\hline Subjective norm & 0.216 & $\mathbf{0 . 7 8 3}$ & & \\
\hline Behavioral control & 0.243 & 0.136 & $\mathbf{0 . 7 9 6}$ & \\
\hline Intention of participation & 0.546 & 0.347 & 0.383 & $\mathbf{0 . 8 1 5}$ \\
\hline
\end{tabular}

\begin{tabular}{|c|c|c|c|c}
\hline $\begin{array}{c}\text { Average extracted } \\
\text { variance (AVE) }\end{array}$ & 0.6074 & 0.6127 & 0.634 & 0.664 \\
\hline Composite reliability & 0.8227 & 0.8259 & 0.838 & 0.8875 \\
\hline Cronbach's albha & 0.6774 & 0.6834 & 0.7116 & 0.831 \\
\hline
\end{tabular}

Source: own

\subsection{Evaluation of the structural model}

Before evaluating the structural model, it is necessary to evaluate the collinearity of the structural model. The values of tolerance and VIF for each subpart of the structural model were analyzed to evaluate the collinearity. The values are within the established by Hair, Hult, Ringle e Sarstedt (2013), being the tolerance above 0.2 and the VIF below 5 .

To analyze the significance of indicators, the bootstrapping technique was used (EFRON; TIBSHIRANI, 1998). The use of bootstrapping technique to analyze the significance of loadings obtained for the observable variables is not based only on a estimation of model, but calculates estimates of parameters and their confidence intervals based on multiple estimates (HAIR; ANDERSON; TATHAM; BLACK, 2005; HAIR; HULT; RINGLE; SARSTEDT, 2013).

In accordance with the recommendations of Hair, Hult, Ringle e Sarstedt (2013), a resampling from 1,000 samples was carried out, with replacement of 185 cases, which was the amount of survey respondents.

The Student's t-statistic analyzes the hypothesis that the coefficients of correlation are equal to zero. If the results of this test indicate values greater than 1.96, the hypothesis is rejected and the correlation is significant (EFRON; TIBSHIRANI, 1998; HAIR; HULT; RINGLE; SARSTEDT, 2013). The variables PART1 and PART2 present values below 1.96, however, outer loadings of these variables have already been analyzed in the evaluation of formative indicators and according to the suggestion of Hair, Hult, Ringle e Sarstedt (2013) they should be kept in the model.

Table 5 presents the values of coefficients between the constructs and their respective Student's t-statistics. The values were estimated by bootstrapping technique.

All values of the relationships presented Student's $t$ values greater than 1.96 (significance level $=5 \%$ ). 
Table 5. Coefficients of the structural model - between constructs

\begin{tabular}{lcccc} 
& Average & $\begin{array}{c}\text { Standard } \\
\text { error }\end{array}$ & t-value & p-valu \\
\hline Attitude -> Intention of participation & 0.441 & 0.050 & 8.711 & 0.000 \\
Attitude -> Participation & 0.160 & 0.043 & 3.614 & 0.000 \\
Subjective norm -> Intention of participation & 0.227 & 0.061 & 3.576 & 0.000 \\
Subjective norm -> Participation & 0.081 & 0.026 & 2.961 & 0.003 \\
Behavioral control -> Intention of participation & 0.241 & 0.067 & 3.638 & 0.000 \\
Behavioral control -> Participation & 0.300 & 0.068 & 4.287 & 0.000 \\
Intention of participation -> Participation & 0.362 & 0.085 & 4.153 & 0.000
\end{tabular}

Source: own

To evaluate the coefficient of determination $\left(\mathrm{r}^{2}\right)$, the studies of Cohen (1988) and Faul, Erdfelder, Lang and Buchner (2007) were used, which determine that $\mathrm{f}^{2}$ values equal to 0.02 , 0.15 and 0.35 are considered, respectively, as small, medium and large effects. These $\mathrm{f}^{2}$ values represent values of $\mathrm{r}^{2}$ equal to $2 \%, 13 \%$ and $25 \%$, respectively.

According to the responses, the construct of Intention of participation in feminist movements presented a $\mathrm{r}^{2}$ of 0.431 , considered high, while the construct Participation in feminist movements presented a $\mathrm{r}^{2}$ of 0.221 , considered between medium and high. The model resulting from the research is presented in Figure 2.

Figure 2. Model resulting from research

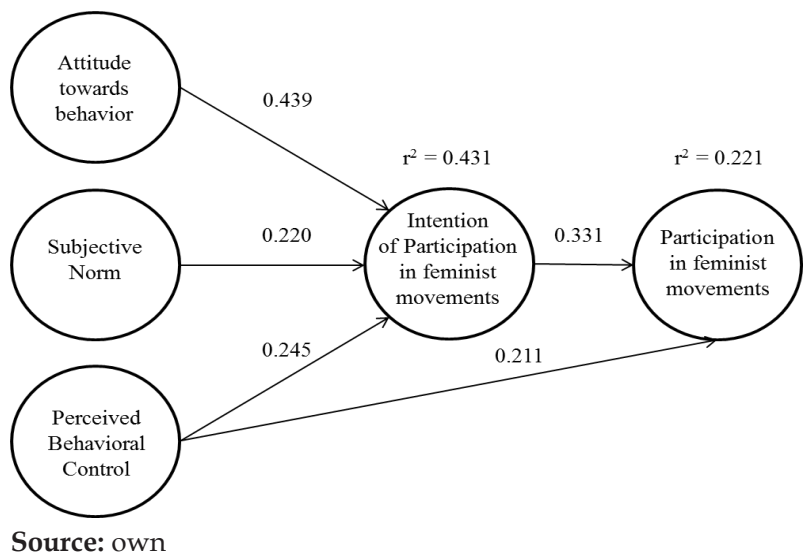

Besides evaluating the magnitude of $\mathrm{r}^{2}$ values as a criterion of predictive accuracy, it is necessary to evaluate the value $\mathrm{q}^{2}$, which is an indicator of predictive relevance of the model. The measure $\mathrm{q}^{2}$ applies a technique of example reusing that omits part of the data matrix and uses the model estimates to predict the omitted part. Specifically, when a model PLS-SEM presents predictive relevance, it accurately predicts the data points of the indicators in measuring reflective models. Table 6 presents the values of $r^{2}$, adjusted $\mathrm{r}^{2}$ and $\mathrm{q}^{2}$. As the procedure does not apply to formative constructs, the value of $\mathrm{q}^{2}$ for the construct Participation is not presented.

Table 6. Results of the values of $\mathrm{r}^{2}$ and $\mathrm{q}^{2}$

\begin{tabular}{lccc}
\cline { 2 - 4 } & $\mathbf{r}^{2}$ & Adjusted $\mathbf{r}^{2}$ & $\mathbf{q}^{2}$ \\
\hline $\begin{array}{c}\text { Intention of } \\
\text { participation }\end{array}$ & 0.431 & 0.422 & 0.264 \\
\hline Participation & 0.221 & 0.212 & 0.135 \\
\hline
\end{tabular}

Source: own

For SEM models, $\mathrm{q}^{2}$ values greater than zero for a specific reflective endogenous latent variable indicate the predictive relevance of the path model. In the case of this study, the values were 0.264 and 0.135 .

To test hypothesis 6 of the study, regarding differences between the relationships of the behavior background of Intention of participation in social movements among young and adult women, a multi-group analysis was performed.

In the survey, 148 respondents were considered Brazilian young women (age up to 24 years old) and 37 were considered Brazilian adult women.

Table 7 presents results of the analysis of relationships of constructs between groups of Brazilian young women and Brazilian adult women respondents. 
Table 7. Analysis of relationships of the research model through young and adult differentiation

\section{Diffe re nce of coefficie nts} (young vs adult)

\section{p-value}

\section{Attitude -> Intention of participation \\ Subjective norm -> Intention of participation \\ Behavioral control -> Intention of participation}

0.234

0.980

0.240

0.029

0.300

0.983

Source: own

The results in Table 7 show that there are significant differences in relationships among constructs Attitude, Subjective Norm and Behavioral Control with Intention of Participation in feminist movements online. The Attitude regarding the adult woman's participation in protests is more intense than in the young woman and that Perceived Behavioral Control influences more the adult woman than the young. It is also noticed that the Social Norm influences more in the case of young women.

The synthesis of the study hypotheses tests (Table 8) were obtained with validations obtained from the structural model.

Table 8. Synthesis of the study hypotheses tests

\begin{tabular}{|l|l|l|}
\hline Hypotheses & Description & Result \\
\hline H1 & $\begin{array}{l}\text { The Attitude towards participation in feminist movements positively } \\
\text { influences the Intention of Participation in the feminist movements online. }\end{array}$ & CONFIRMED \\
\hline H2 & $\begin{array}{l}\text { The Subjective Norm positively influences the Intention of Participation } \\
\text { in feminist movements online. }\end{array}$ & CONFIRMED \\
\hline H3 & $\begin{array}{l}\text { The Perceived Behavioral Control positively influences the Intention of } \\
\text { Participation in feminist movements online. }\end{array}$ & CONFIRMED \\
\hline H4 & $\begin{array}{l}\text { The Perceived Behavioral Control positively influences the Intention of } \\
\text { Participation in feminist movements online. }\end{array}$ & CONFIRMED \\
\hline H5 & $\begin{array}{l}\text { The Intention of Participation in feminist movements online positively } \\
\text { influences the Participation in movements. }\end{array}$ & CONFIRMED \\
\hline H6a & $\begin{array}{l}\text { The woman's age moderates the relationship between Attitude towards } \\
\text { behavior and Intention of Participation in feminist movements. }\end{array}$ & CONFIRMED \\
\hline H6b & $\begin{array}{l}\text { The woman's age moderates the relationship between Subjective Norm } \\
\text { and Intention of Participation in feminist movements. }\end{array}$ & CONFIRMED \\
\hline H6c & $\begin{array}{l}\text { The woman's age moderates the relationship between perceived Behavioral } \\
\text { Control and Intention of Participation in feminist movements. }\end{array}$ & CONFIRMED \\
\hline
\end{tabular}

Source: own

Inf. \& Soc.:Est., João Pessoa, v.27, n.2, p. 219-234, maio/ago. 2017 


\section{CONCLUSIONS}

From a macro-historical analysis since the first wave of feminism, with the suffragists claiming the right to vote, or in the second feminist wave, with women fighting for greater participation in public spaces and also for civil rights, the feminist movement (like other social movements) presented itself as a movement built in plural form with the participation of various social, economic and political actors.

According to Saracevic (1996), the area of Information Science presented contributions that influenced the way information is manipulated in society and technology. Currently, many women have used online social networks as a tool to report harassment, or even organize activities, discussions and protests. Because of the easy access and the possibility of anonymity, social networks helped a greater and more rapid spread of the feminist movement. However, being a heterogeneous movement, it is formed by other factors and by different ways in different geographic locations.

The campaign \#meuamigosecreto had national and international proportions, and the use of internet had a decisive role in the diffusion of information sharing. As the denunciation was anonymous, many men did not know in fact who was being targeted. This often caused questioning and doubts in people, assisting and encouraging other women to disclose information, denouncing cases that normally they did not have the courage to denounce.

This study aimed to identify the elements that influence the Intention of Participation of women in feminist movements online, and it confirmed all hypotheses and presented a robust model, with $\mathrm{r}^{2}$ of $41 \%$ for Intention of Participation in feminist movements online.

The results indicate that the Attitude regarding the behavior is the construct that most influences the Intent of Participation in feminist movements online. Therefore, women believe that their participation strengthens the feminist movement, can result in a reduction in cases of violence against women, contributes to the debate on the topic and makes men become aware of their macho attitudes.

The Perceived Behavioral Control is the second most influential factor. Because of the ease to post, comment, like and share the reports with the hashtag meu amigo secreto, women end up adhering to the movement.

The Subjective Norm appears as the third factor, but with influence almost equal to Behavioral Control. This indicates that social pressure from female friends and family positively influence women to participate in the movement. When they realize that other colleagues are participating online, they decide to contribute as well.

According to the results, it was also possible to conclude that there are differences between the perceptions of the young and the adult woman. In the case of attitude towards participation in protests, the influence on adult women is more intense than on the young women. This indicates that the belief of the adult woman in the contributions of participating in the movement is greater.

In relation to the Perceived Behavioral Control, the influence is also greater in adult women. This result may indicate that the fact that young women have more easiness with the technology makes the factor influence less her behavior.

The Subjective Norm influences more in the case of the young woman, which indicates that the influence of other people's opinion is greater in the young than in the adult woman.

This study fills an important gap between gender researches and Information Science, because while there are several studies in Information Science that stimulate information to reduce social problems, there are few studies about violence against women (CÔRTES; ARAUJO; SILVA, 2014).

In addition, results of the research collaborate with studies on digital activism, increasing the understanding in a critical short-term event (AGARWAL et al., 2014; GHOBADI; CLEGG, 2015; LEONG et al., 2015; OH; AGRAWAL; RAO, 2013; WATTAL et al., 2010) in a context not yet explored. The understanding of the social media influence, with the factors that influence women's intention to participate in feminist movements online, also collaborates with the gap in researches on the influence of social media on collective action movements (BENNETT; SEGERBERG, 2011; GIL DE ZÚÑIGA; JUNG; VALENZUELA， 2012; TUFEKCI; WILSON, 2012). 
Limitations of the study include: the sample representativeness, which obtained 185 respondents among the movement participants; there may be measurement errors due to imprecision in the measurement of the actual values by applying the online questionnaire; the survey was conducted with a single cross section; perception and ability of researchers to develop the questionnaire and analyze its results.

Some suggestions for future studies: replicate the research in new online movements, feminist or not; perform qualitative researches to study the women perceptions; research other contexts, countries, states, communities; conduct longitudinal studies.

Artigo recebido em 09/02/2017 e aceito para publicação em 31/03/2017

\section{PARTICIPAÇÃO EM MOVIMENTOS FEMINISTAS BRASILEIROS EM REDES SOCIAIS: um estudo sobre a campanha Meu Amigo Secreto (My Secret Santa)}

RESUMO: $\quad$ O feminismo é um movimento social e político que combate sistemas que criam desigualdades que sustentam os estratos relacionados às mulheres, lutando contra $\circ$ racismo, a opressão de classes e o patriarcalismo. Recentemente muitas mulheres buscaram a internet como meio de expressão e reivindicação, e através delas realizaram campanhas de impacto nacional e internacional, disseminando informações usando os hashtags \#meuamigosecreto (\#mysecretsanta) e \#meuprimeiroassédio (\#myfirstharassment), através dos quais as mulheres denunciaram situações de vários tipos de assédio que experimentaram. O objetivo deste estudo foi identificar quais são os elementos que influenciam a intenção da participação das mulheres nos movimentos feministas online. Foi realizada uma pesquisa com I 85 mulheres brasileiras que participaram da campanha \#meuamigosecreto. A metodologia utilizada foi quantitativa e os dados foram analisados por modelos de equações estruturais. $O$ estudo mostrou um modelo robusto com alto valor explicativo. Os resultados indicam que a Atitude em relação ao comportamento, Norma Subjetiva e Controle de Comportamento Percebido influencia positivamente na Intenção de Participação em movimentos feministas on line e que a Intenção influencia diretamente na Participação efetiva. Além disso, os testes indicam que há uma diferença significativa entre as percepções de mulheres jovens e adultas. A pesquisa fornece informações relevantes para uma melhor compreensão dos movimentos feministas online, demonstrando que os participantes acreditam que as campanhas fortalecem o movimento feminista, ajudam a conscientizar os homens sobre suas atitudes machistas, podem resultar em uma diminuição dos casos de violência contra as mulheres e contribuir para o debate sobre a violência contra as mulheres.

Palavras-chave: Internet. Redes sociais. Feminismo. Movimentos sociais on line.

\section{REFERENCES}

AGARWAL, S. D. et al. Grassroots Organizing in the Digital Age: Considering Values and Technology in Tea Party and Occupy Wall Street. Information, Communication \& Society, v.17, n.3, p. 326-341, 2014.
AJZEN, I. Consumer attitudes and behavior. In C.P. Haugtvedt; P. M. Herr \& F. R. Cardes (Eds.), Handbook of consumer psychology. New York: Lawrence Erlbaum Associates, 2008, p. 525-548.

AJZEN, I.; FISHBEIN, M. Understanding attitudes and predicting social behavior. Englewood Cliffs, New Jersey: Prentice Hall, 1980. 
ARAÚJO, I. O.; FARONE W. Os movimentos sociais no contexto da Administração no Brasil. In: EnANPAD 2015, 2015, Belo Horizonte. XXXIX Encontro da ANPAD, 2015. v. 39. p. 1-16, 2015.

BALDASSARI, D.; DIANI, M. The Integrative Power of Civic Networks. American Journal of Sociology, v.113, n.3, p. 735-780, 2007.

BEARMAN, P. S.; EVERETT, K. D. The Structure of Social Protest, 1961-1983. Social Networks, v.15, p.171-200, 1993.

BENNETT, W. L.; SEGERBERG, A. Digital Media and the Personalization of Collective Action: Social Technology and the Organization of Protests Against the Global Economic Crisis. Information, Communication \& Society, v.14, n.6, p. 770-799, 2011.

BOURDIEU, P. Contrafogos - 2: Por um movimento social europeu. Rio de Janeiro: Zahar, 2001.

BOYD, D. M.; ELLISON, N. B. Social network sites: definition, history, and scholarship. Journal of Computer-Mediated Communication, v.13, n.1, article 11, 2007.

BUSCHT, T. Attitudes towards management by objectives: An empirical investigation of selfeffi cacy and goal commitment. Scandinavian Journal of Management, v.14, n.3, p. 289-299, 1998.

CAPURRO, R.; HJORLAND, B. O conceito de informação. Perspectivas em Ciências da Informação, v.12, n.1, p. 148-207, 2007.

CHIN, W. W. The Partial Least Squares Approach to Structural Equation Modeling. In G. A. Marcoulides (Ed.), Modern Methods for Business Research (pp. 295-358). Mahwah, NJ: Lawrence Erlbaum, 1998.

CHIN, W. W.; NEWSTED, P. R. Structural equation modeling analysis with small samples using partial least squares. In R. H. Hoyle (Ed.), Statistical strategies for small sample research (pp. 307-341). Thousand Oaks, CA: Sage Publications, 1999.

COHEN, J. Statistical power analysis for the behavioral sciences (2nd edition). Hillsdale, NJ: Lawrence Erlbaum Associates, 1988.
CÔRTES, G. R.; ARAUJO, W. J.; SILVA, D. L. Sistema atende mulher: sistema de informação no Centro de Referência da Mulher Ednalva Bezerra. Informação \& Sociedade: Estudos, João Pessoa, v.24, n.2, p. 85-95, 2014.

CRENSHAW, K. Documento para o Encontro de Especialistas em Aspectos da Discriminação Racial Relativos ao Genêro. Revista Estudos Feministas, Ano 10, p. 171-188, 2002.

EFRON, B.; TIBSHIRANI, R. J. An introduction to the bootstrap. London: Chapman \& Hall, 1998.

FARIA, J. Hashtag transformação: 82 mil tweets sobre o \#PrimeiroAssedio. Available at: $\quad$ http://thinkolga.com/2015/10/26/ hashtag-transformacao-82-mil-tweets-sobre-oprimeiroassedio/>. Accessed on: Jan. $5^{\text {th }} 2016$.

FAUL, F.; ERDFELDER, E.; LANG, A.-G.; BUCHNER, A. G*Power 3: A flexible statistical power analysis program for the social, behavioral, and biomedical sciences. Behavior Research Methods, v.39, p. 175-191, 2007.

FRANÇA, A. L. D.; NETO, J. A. S. P.; DIAS, G. A. A ciência da informação e o pensamento de Bruno Latour: implicações para a análise de redes sociais. Informação \& Sociedade: Estudos, João Pessoa, v.25, n.1, p. 137-144, 2015.

FISHBEIN, M.; AJZEN, I. Belief, attitude, intention, and behavior: An introduction to theory and research. Reading, MA: AddisonWesley, 1975.

FORNELL, C.; LARCKER, D. F. Evaluating structural equation models with unobservable variables and measurement error. Journal of Marketing Research, v.18, p.39-50, 1981.

GHOBADI, S.; CLEGG, S. These Days Will Never Be Forgotten...: A Critical Mass Approach to Online Activism. Information and Organization, v.25, n.1, p. 52-71, 2015.

GIL DE ZÚÑIGA, H.; JUNG, N.; VALENZUELA, S. Social Media Use for News and Individuals' Social Capital, Civic Engagement and Political Participation. Journal of Computer-Mediated Communication, v.17, n.3, p. 319-336, 2012.

GOULD, R. V. Trade Cohesion, Class Unity, and Urban Insurrection: Artisanal Activism in the 
Paris Commune. American Journal of Sociology, v.98, n.4, p. 721-54, 1993.

HAIR, J. F.; ANDERSON, R. E.; TATHAM, R. L.; BLACK, W. C. Análise multivariada de dados. $5^{a}$ Ed. Porto Alegre: Bookman, 2005.

HAIR, J. F.; HULT, G. T. M.; RINGLE, C. M.; SARSTEDT, M. A Primer on Partial Least Squares Structural Equation Modeling (PLSSEM). Thousand Oaks: SAGE Publications, 2013.

HAIR, J. F.; RINGLE, C. M.; SARSTEDT, M. PLS-SEM: Indeed a Silver Bullet. Journal of Marketing Theory and Practice, v. 19, p. 139-151, 2011.

LEONG, C. M. L. et al. ICT-Enabled Community Empowerment in Crisis Response: Social Media in Thailand Flooding 2011. Journal of the Association for Information Systems, v.16, n.3, p. 174-212, 2015.

MELUCCI, A. A invenção do presente: movimentos sociais nas sociedades complexas. (M. C. A. Bomfim, Trad.). Petrópolis, Rio de Janeiro: Vozes, 2001.

MORAES, G. H. S. M.; CAPPELLOZZA, A.; MEIRELLES, F. S. \#VEMPRARUA: A Tecnologia da Informação e as Manifestações Sociais: Um Estudo da Utilização das Redes Sociais para Participação nos Protestos. In: EnANPAD 2014, 2014, Rio de Janeiro. XXXVIII Encontro da ANPAD, 2014. v. 38, p. 1-16, 2014.

NETEMEYER, R. G.; BEARDEN, W. O.; SHARMA, S. Scaling procedures: issues and applications. Thousand Oaks, CA: Sage Publications, 2003.

NHACUONGUE, J. A; FERNEDA, E. O campo da ciência da informação: contribuições, desafios e perspectivas. Perspectivas em Ciência da Informação, v.20, n.2, p. 3-18, 2015.

NUNALLY, J. C.; BERNSTEIN, I. Psychometric theory. New York: McGraw-Hill, 1994.

$\mathrm{OBACH}$, B. Labor and the Environmental Movement: The Quest for Common Ground. Cambridge, MA: MIT Press, 2004.

OH, O.; AGRAWAL, M.; RAO, H. R. Community Intelli-gence and Social Media Services: A Rumor
Theoretic Analysis of Tweets During Social Crises. MIS Quarterly, v.37, n.2, p. 407-426, 2013.

PUTNAM, R. Making Democracy Work: Civic Traditions in Modern Italy. Princeton, NJ: Princeton University Press. 1993.

RINGLE, C. M.; WENDE, S.; BECKER, J. SmartPLS 3. Bönningstedt: SmartPLS, 2015.

SCAVONE, L. Religiões, Gênero e Feminismo. Revista de Estudos da Religião. 2008.

SARACEVIC, T. Ciência da Informação: origens, evolução e relação. Perspectivas em Ciência da Informação, v. 1, n. 1, p. 41-62, 1996.

TIMOTEO, C. Q. As transformações do movimento feminista no Brasil e sua relação com a América Latina. In: V Simpósio Internacional Lutas Sociais na América Latina, "Revoluções nas Américas: passado, presente e futuro", GT 7 Feminismos, sexualidades e marxismos na América Latina, 2013, Londrina. Anais... Londrina, p. 91-103, 2013.

TOMAÉL, M. I.; ALCARÁ, A. R.; DI CHIARA, I. G. Das redes à Inovação. Revista Ciência da Informação. Brasília, v. 34, n. 2, p. 93-104, 2005.

TUFEKCI, Z.; WILSON, C. Social Media and the Decision to Participate in Political Protest: Observations from Tahrir Square. Journal of Communication, v.62, n.2, p. 363-379, 2012.

VAN DYKE, N.; MCCAMMON, H. J. Introduction: Social Movement Coalition Formation. In Van Dyke N. \& MacCammon H. J. (Eds.) Strategic Alliances: Coalition Building and Social Movements. Minneapolis: University of Minnesota Press, 2010.

VENKATESH, V.; MORRIS, M. G.; DAVIS, G. B.; DAVIS, F. D. User Acceptance of Information Technology: Toward a Unified View. MIS Quarterly, v.27, n.3, p. 425-478, 2003.

VENKATESH, V.; THONG, J. Y. L.; XU, X. Consumer Acceptance and Use of Information Technology: Extending the Unified The ory of Acceptance and Use of Technology. MIS Quarterly, v. 36, n.1, p. 157-178, 2012.

WANG, D. J.; SOULE, S. A. Social Movement Organizational Collaboration: Networks of 
Learning and the Diffusion of Protest Tactics, 1960-1995. American Journal of Sociology, v.117, n.6, p. 1674-1722, 2012.

WARREN, I. S. Das Mobilizações às Redes de Movimentos Sociais. Revista Sociedade e Estado, Brasília, v. 21, n.1, p. 109-130, jan./abr, 2006.
WATTAL, S. et al. Web 2.0 and Politics: The 2008 U.S. Presidential Election and an E-Politics Research Agenda. MIS Quarterly, v.34, n.4, p. 669-688, 2010.

WHETTEN, D. A. What Constitutes a Theoretical Contribution?. Academy of Management Review, v.14, n.4, p. 490-495, 1989. 